\title{
Effect of histamine on the growth of human gastrointestinal tumours: reversal by cimetidine
}

\author{
S A Watson, L J Wilkinson, J F R Robertson, J D Hardcastle
}

\begin{abstract}
The proliferative effects of histamine were examined on the human gastric tumour cell lines; MKN45, the gastrin producing subline, MKN45G, and the colorectal lines; LoVo and C170. The proliferation of MKN45 as assessed by ${ }^{75}[\mathrm{Se}]$ selenomethionine uptake and cell counts was increased by histamine concentrations of $10^{-7}$ and $10^{-9} \mathrm{M}$. Histamine concentrations between $10^{-6}$ and $10^{-7} \mathrm{M}$ maximally stimulated MKN45G proliferation which titrated out at lower histamine concentrations. The accumulation of cyclic adenosine $3^{\prime}, 5^{\prime}$ monophosphate (cAMP) in response to the same histamine concentrations was also increased in the two gastric cell lines. The histamine receptor antagonist, cimetidine $\left(10^{-5} \mathrm{M}\right)$ reversed the histamine stimulated proliferation of both gastric cell lines despite having no effect on basal growth. The proliferation of the colorectal lines was unaffected by histamine. Histamine given locally at the subcutaneous implantation site of the tumour (1 $\mathrm{mg} / \mathrm{kg} / \mathrm{day}$ ) increased the growth of MKN45G xenografts in nude mice. This was reversed by coadministration of cimetidine (100 mg/kg/day, given in the drinking water). Cimetidine also inhibited the basal proliferation of MKN45 xenografts. Histamine acting locally may enhance the proliferation of tumours arising within the stomach. Such effects may be blocked by administration of histamine receptor antagonists, such as cimetidine.
\end{abstract}

(Gut 1993; 34: 1091-1096)

Gastric cancer is the fourth most common cancer in the United Kingdom causing about 10000 deaths annually in England and Wales alone. Major advances in both surgery and anaesthesia have lowered the death rate from operations, ${ }^{12}$ yet the five year survival remains around 5\% (OPCS Monitor). These dismal survival figures are due to the fact that most patients in the United Kingdom present with advanced disease.

Radiotherapy has no proved value in the treatment of gastric cancer and while there have been numerous trials of various chemotherapy regimens, none have proved to be valuable either as an adjuvant treatment or for advanced disease.

An enhancement in the survival of gastric cancer patients has been reported by Tonnesen et $a l,{ }^{3}$ after treatment with the histamine ${ }_{2}$ receptor antagonist, cimetidine. The median survival in the cimetidine treated group was significantly greater then in the placebo group (450 days compared with 316 days). It is imperative to investigate the mechanism of action of this treatment because of the small therapeutic bene- fits found with older regimens of treatment, which have been used for patients with gastric cancer.

One of the mechanisms postulated to play a part in the anti-tumour effect of cimetidine is immunomodulation mediated by the inhibition of suppressor $\mathrm{T}$ cell activity, ${ }^{45}$ an increase in interleukin 2 production in helper T cells, ${ }^{6}$ and an enhancement of natural killer cell activity. ${ }^{7-9}$

In this study the role of histamine as a mitogenic agent for tumours in the gastrointestinal tract was investigated to discover if cimetidine may block such proliferation enhancing effects.

\section{Methods}

\section{CELL LINES}

MKN45 is a human gastric adenocarcinoma ${ }^{10}$ and MKN45G is a gastrin producing subline of MKN45." LoVo is a human colon adenocarcinoma $^{12}$ and $\mathrm{C170}$ a human colorectal adenocarcinoma cell line derived in the Cancer Research Campaign Laboratories, Nottingham. ${ }^{13}$ The two gastric lines were maintained in Dulbecos modified Eagles medium (Flow Laboratories, Irvine, Scotland, UK) with $10 \%$ heat inactivated fetal calf serum (Gibco, Paisley, Scotland, UK). The two colon lines were grown in RPMI medium (Gibco) with $10 \%$ fetal calf serum. All lines were maintained in a humidified incubator at $37^{\circ} \mathrm{C}$, gassed with $5 \% \mathrm{CO}_{2}$, and were $\mathrm{refed} / \mathrm{harvested}$ twice weekly.

\section{EFFECT OF HISTAMINE AND CIMETIDINE ON IN} VITRO CELL GROWTH

\section{Direct cell counts}

Cells were plated into 24 well plates (Gibco) at a concentration of $10^{5}$ well $^{-1}$, in Biorich serum free growth medium (Flow Labs). After allowing for cell adherence, increasing concentrations of histamine $\left(10^{-6}\right.$ to $10^{-10} \mathrm{M}$, Sigma, Dorset, UK) or cimetidine $\left(10^{-5}\right.$ to $\left.10^{-10} \mathrm{M}\right)$ were added to the wells either alone or in combination giving a final well volume to $500 \mu \mathrm{l}$. After three to four days incubation at $37^{\circ} \mathrm{C}$ the cells were harvested with $0.025 \%$ trypsin/0.5\% EDTA (Sigma) and viable cells were counted with a haemocytometer (viability was assessed by trypan blue exclusion). Three replicates were performed per dilution.

\section{${ }^{75}[\mathrm{~S}$ e] selenomethionine incorporation}

${ }^{75}$ [Se] selonamethionine uptake is a measure of protein synthesis and thus is an indirect measure of cell proliferation.

Cells were plated into 96 well plates (Gibco) in 
Biorich at a concentration of $10^{4}$ well $^{-1}$. After the cells had adhered, the histamine and cimetidine concentrations described above were added to the wells giving a final well volume of $200 \mu \mathrm{l}$. After three to four days incubation the cells were pulsed with $0 \cdot 1 \mu \mathrm{Ci}^{75}$ [Se] selenomethionine (CIS UK, High Wycombe, Bucks, UK) in a volume of $50 \mu \mathrm{l}$ for 18 hours. The cells were then vigorously washed and radioactivity associated with individual wells counted on a gammacounter (counting efficiency $>80 \%$ ). Five replicates were performed per dilution.

Effects of cimetidine and histamine on the proliferation of the cells were calculated as a percentage of the untreated controls.

\section{Measurement of histamine $(\mathrm{H} 2)$ receptors}

This was performed by an indirect method in which the concentrations of intracellular cyclic adenosine $3^{\prime}, 5^{\prime}$ monophosphate (cAMP) are assessed, after incubation of histamine with the cells. cAMP functions as a second messenger after binding of histamine to the histamine ${ }_{2}$ receptor. The assay was performed by the use of a cAMP radioimmunoassay kit (NEN DuPont, Stevenage, Hertfordshire, UK). Briefly, cell monolayers were harvested by gentle scraping, washed, and suspended in Krebs Ringer phosphate buffer; pH $7 \cdot 5$ at $5 \times 10^{6}$ cells $\mathrm{ml}^{-1}$. The cells were agitated gently for one hour in the absence/presence histamine. The reaction was stopped by the addition of $11 \mathrm{~N} \mathrm{HCLO}_{4}$ and the cells were centrifuged at $4000 \mathrm{~g}, 10$ minutes. $9 \mathrm{~N}$ $\mathrm{KOH}$ was added to the supernatant to remove perchlorate ions followed by succinic anhydride $(6 \cdot 15 \mathrm{mg} / \mathrm{ml})$. To assess recovery of cAMP a $3[\mathrm{H}]$ cAMP marker (DuPont) was added to alternate tubes (4000 cpm/tube) and percentage recovery assessed.

cAMP concentrations were acetylated before measurement to increase the sensitivity of the assay. cAMP standards were prepared ranging from $0 \cdot 1$ to $4 \mathrm{pmol} \mathrm{ml}^{-1}$ and standards and unknowns were competed with ${ }^{125}[\mathrm{I}]$ succinyl cAMP tyrosine methyl ester $\left(4.5 \times 10^{4} \mathrm{cpm}\right.$ tube $^{-1}$ ) for binding to a fixed concentration of cAMP antiserum in sodium phosphate buffer, $\mathrm{pH}$ 6. All tubes were mixed and incubated overnight at $4^{\circ} \mathrm{C}$. After precipitation by trichloroacetic acid, the tubes were centrifuged at $2-8^{\circ} \mathrm{C}$ for 15 minutes at $1200 \mathrm{~g}$. The supernatant was discarded and the precipitate counted on a gammacounter.

EFFECT OF HISTAMINE/CIMETIDINE ON THE IN VIVO GROWTH OF MKN45G

MKN45G xenografts were initiated in male nude mice (Harlan-Olac, Bicester, UK) (weight $35 \mathrm{~g}$, age 8-10 weeks) by a subcutaneous injection of $10^{7}$ cells (in a $200 \mu \mathrm{l}$ volume of sterile phosphate buffered saline (PBS)) into the left hand flank. Once the xenografts were established, they were aseptically excised, mechanically minced, and $3 \mathrm{~mm}^{3}$ cubed pieces of tissue grafted into the experimental animals. The animals were then randomised into different treatment groups.

Histamine was given in doses of 1,5 , and 10 $\mathrm{mgkg}^{-1}$ day $^{-1}$ in a $100 \mu \mathrm{l}$ injection directly into the site of the grafted tissue. The control group were injected in an identical manner with $100 \mu \mathrm{l}$ volume of the histamine diluent (PBS). The mice were injected daily from day 0 until the experiment was finished.

Cimetidine was given at a dose of $100 \mathrm{mgkg}^{-1}$ day $^{-1}$ in the drinking water of the animals studied. This dose produces a murine plasma concentration of 0.16 to $0.35 \mu \mathrm{g} \mathrm{ml}^{-1}$, which was the most effective dose in a syngeneic tumour model. ${ }^{14}$ The dose in the water was calculated from the observation that a $35 \mathrm{~g}$ mouse drank $6 \mathrm{ml}$ of water day ${ }^{-1}$. The cimetidine was replenished every day and was given from day 0 to the end of the experiment. UKCCCR Guidelines were adhered to throughout all animal experimentation.

Histological analysis of the MKN45G xenografts After the finish of the in vivo experiments, xenografts were surgically removed and fixed in $0 \cdot 1 \%$ paraformaldehyde. Sections were cut on a microtome and stained with haematoxylin and eosin to show the nucleii and cytoplasm of cells within the xenografts. The xenografts were examined blind by an independent pathologist and assessed for percentage of necrosis within the tumour, shape of nucleii, and cohesiveness of cells.

\section{STATISTICAL ANALYSIS}

In vitro data were analysed by a one way analysis of variance. The in vivo data were analysed by the Mann-Whitney U Wilcoxon analysis of variance and multiple analysis of variance (MANOVA) tests by use of the SPSS/PC+ and the mini-tab statistical packages for the IBM PC.

\section{Results}

IN VITRO STUDIES

\section{Effect of histamine on the in vitro growth of} established gastrointestinal cell lines

In vitro growth, in the presence of histamine was measured by both ${ }^{75}[\mathrm{Se}]$ selenomethionine uptake and direct cell counts. Results are expressed as the percentage of the untreated control. Five replicates were performed per drug dilution and the standard deviation of the mean is shown.

TABLE I Effect of histamine on the proliferation of MKN45 as analysed by $(A)^{75}[\mathrm{Se}$ ] selenomethionine uptake and $(B)$ direct cell counts

\begin{tabular}{llllll}
\hline \multirow{2}{*}{$\begin{array}{l}\text { Experiment } \\
\text { No }\end{array}$} & \multicolumn{5}{c}{$\%$ Untreated control $(S D)$ histamine concentration $(M)$} \\
\cline { 2 - 6 } & 0 & $10^{-6}$ & $10^{-7}$ & $10^{-8}$ & $10^{-9}$ \\
\hline $\mathrm{A}^{75}[$ Se] selonomethionine uptake & & & \\
1 & $100(5)$ & $176(8)^{\star}$ & $156(10)^{\star}$ & $100(4)$ & $131(7)^{\star}$ \\
2 & $100(6)$ & $217(5)^{\star}$ & $177(15)^{\star}$ & $122(11)$ & $120(7)^{\star}$ \\
3 & $100(1)$ & $146(12)^{\star}$ & $141(4)^{\star}$ & $114(2)$ & $145(9)^{\star}$ \\
4 & $100(2)$ & $149(2)^{\star}$ & $135(5)^{\star}$ & $129(1)^{\star}$ & $166(1)^{\star}$ \\
B Direct cell counts & & & & & \\
1 & $100(2)$ & $144(14)^{\star}$ & $138(9)^{\star}$ & $122(4)^{\star}$ & $163(10)^{\star}$ \\
2 & $100(6)$ & $148(7)^{\star}$ & $149(15)^{\star}$ & $89(7)$ & $171(22)^{\star}$ \\
3 & $100(8)$ & $211(7)^{\star}$ & $195(15)^{\star}$ & $123(4)^{\star}$ & $123(5)^{\star}$ \\
4 & $100(2)$ & $131(5)^{\star}$ & $128(6)^{\star}$ & $96(8)$ & $131(18)^{\star}$ \\
\hline
\end{tabular}

^Significant from the untreated control as analysed by a one way analysis of variance. 
TABLE II Effect of histamine on the proliferation of $M K N 45 G$ as analysed by $(A)^{75}[\mathrm{Se}]$ selenomethionine uptake and $(B)$ direct cell counts

\begin{tabular}{llllll}
\hline \multirow{2}{*}{ Experiment } & \multicolumn{5}{c}{$\%$ Untreated control (SD) histamine concentration $(M)$} \\
\cline { 2 - 6 } No & 0 & $10^{-6}$ & $10^{-7}$ & $10^{-8}$ & $10^{-9}$ \\
\hline $\mathrm{A}^{75}[$ Se] selonomethionine uptake & & & \\
1 & $100(2)$ & $264(13)^{\star}$ & $264(8)^{\star}$ & $121(4)^{\star}$ & $103(8)$ \\
2 & $100(7)$ & 157()$^{\star}$ & $165(7)^{\star}$ & $119(9)$ & $93(3)$ \\
3 & $100(3)$ & $162(13)^{\star}$ & $111(15)$ & $87(8)$ & $89(6)$ \\
4 & $100(3)$ & $148(16)^{\star}$ & $164(4)^{\star}$ & $137(5)^{\star}$ & $106(2)$ \\
B Direct cell counts & & & & \\
1 & $100(4)$ & $112(7)$ & $146(15)^{\star}$ & $127(1)^{\star}$ & $96(6)$ \\
2 & $100(10)$ & $144(7) \star$ & $146(2)^{\star}$ & $109(3)$ & $96(2)$ \\
3 & $100(8)$ & $139(6){ }^{\star}$ & $133(9)^{\star}$ & $127(4)^{\star}$ & $107(9)$ \\
4 & $100(2)$ & $125(6)^{\star}$ & $139(7)$ & $105(11)$ & $92(7)$ \\
\hline
\end{tabular}

«Significant from the untreated control as analysed by a one way analysis of variance.

Table I shows the effect of increasing histamine concentrations $\left(10^{-9}\right.$ to $\left.10^{-6} \mathrm{M}\right)$ on MKN45 as assessed by (a) ${ }^{75}[\mathrm{Se}]$ selenomethionine uptake ( $n=$ four sequential experiments) and (b) direct cell counts $(n=$ four sequential experiments). Histamine at concentrations of $10^{-6}, 10^{-7}$, and $10^{-9} \mathrm{M}$ significantly increased the growth of MKN45 as assessed by both assays, in all experiments.

Histamine also increased the growth of MKN45G cells (Table II). A dose response curve was obtained as assessed by label uptake, with histamine concentrations of $10^{-8}, 10^{-7}$, and $10^{-6} \mathrm{M}$ all increasing uptake significantly but with the maximum response obtained between $10^{-6}$ and $10^{-7} \mathrm{M}$ in four sequential experiments with both (a) ${ }^{75}[\mathrm{Se}]$ selenomethionine uptake and (b) direct cell counts.

Histamine at concentrations greater than $10^{-6}$ $M$ were shown to affect the viability of the cells in the in vitro culture system and so could not be examined satisfactorily. Histamine had no effect on the in vitro growth of the colorectal cell lines: LoVo and $\mathrm{C170}$ as assessed by the two assays (data not shown).

Histamine receptor state of the gastrointestinal cell lines as assessed by cAMP accumulation

Histamine receptors, indirectly measured by cAMP accumulation were found to be present on MKN45, MKN45G but not C170 or LoVo (Table III). All cell lines were found to have the

TABLE III Accumulation of cAMP by the tumour cells in response to incubation of whole cells with histamine

\begin{tabular}{llll}
\hline Cell line & $\begin{array}{l}\text { Histamine } \\
\text { concentration } \\
(M)\end{array}$ & $\begin{array}{l}\text { cAMP } \\
\text { concentrations } \\
(\text { pmol/l/ml })(\text { mean })\end{array}$ & $\begin{array}{l}\% \\
\text { Untreated } \\
\text { control }\end{array}$ \\
\hline MKN45 & 0 & $2 \cdot 30$ & \\
& $10^{-6}$ & $2 \cdot 18^{\star}$ & 95 \\
& $10^{-7}$ & $4 \cdot 37 \dagger$ & 190 \\
& $10^{-8}$ & $2 \cdot 46^{\star}$ & 107 \\
MKN45G & $10^{-9}$ & $3 \cdot 41 \ddagger$ & 148 \\
& 0 & $2 \cdot 26$ & 147 \\
& $10^{-6}$ & $3 \cdot 339$ & 135 \\
C170 & $10^{-7}$ & $3 \cdot 06 \ddagger$ & 128 \\
LoVo & $10^{-8}$ & $2 \cdot 89 \ddagger$ & 105 \\
& $10^{-9}$ & $2 \cdot 38^{\star}$ & 100 \\
& 0 & $2 \cdot 38$ & 98 \\
\hline
\end{tabular}

Mean is of three replicates. Numbers in superscripts refer to the value of significance from the untreated control value; ${ }^{\star}$ nonsignificant, $t \mathrm{p}<0.02 ; \neq \mathrm{p}<0.05, \S \mathrm{p}<0.001$.
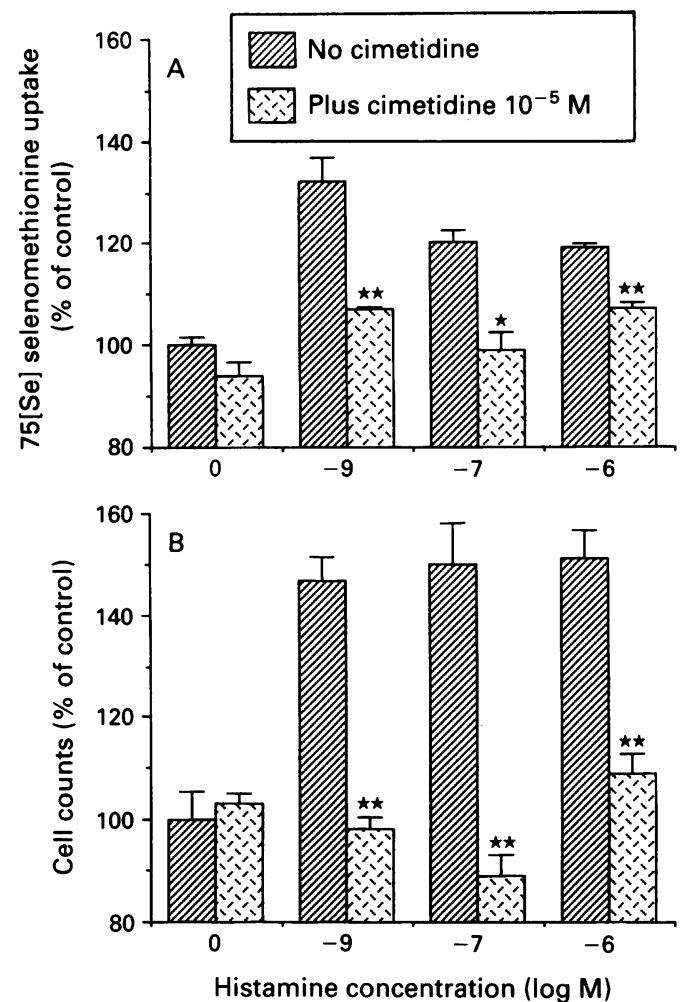

Figure 1: Effect of cimetidine on the histamine stimulated growth of MKN45 as assessed by $(A)^{75}[S e]$ selomethionine uptake (mean of four experiments) and $(B)$ direct cell counts (mean of four experiments). ${ }^{\star} p<0.01,{ }^{\star \star} p<0.001$ when compared with histamine stimulated growth.

same basal concentration of cAMP. In response to histamine, MKN45 cells had significantly raised concentrations of cAMP in the presence of $10^{-7}$ and $10^{-9} \mathrm{M}$ histamine, which corresponds with the proliferation data previously shown. MKN45G cells responded in a dose dependent way to histamine from $10^{-6}$ to $10^{-9} \mathrm{M}$, with $10^{-6} \mathrm{M}$ histamine inducing the highest concentration of CAMP accumulation.

Effect of cimetidine on the basal in vitro growth of $M K N 45$ and $M K N 45 G$

Cimetidine used at concentrations from $10^{-5}$ to $10^{-10} \mathrm{M}$ had no significant effect on the basal growth of MKN45, MKN45G, C170, and LoVo cells as assessed by both ${ }^{75}[\mathrm{Se}]$ selenomethionine uptake and direct cell counts (data not shown).

\section{Effect of cimetidine on the histamine stimulated} growth of MKN45 and MKN45G

Histamine concentrations of $10^{-9}, 10^{-7}$, and $10^{-6} \mathrm{M}$ significantly increased the growth of MKN45, and these were significantly reversed to values of the untreated control by coincubation with $10^{-5} \mathrm{M}$ cimetidine as shown by label uptake (Fig 1 (A) mean of four separate experiments) and direct cell counts (Fig 1 (B) mean of four separate experiments). Cimetidine has no significant effect on the basal growth.

Cimetidine at a fixed concentration of $10^{-5} \mathrm{M}$ significantly reduced growth stimulated by $10^{-8}$ $10^{-7}$, and $10^{-6} \mathrm{M}$ histamine of MKN45G as assessed by ${ }^{75}[\mathrm{Se}]$ selenomethionine uptake (Fig 2 (A), mean of four separate experiments) and direct cell counts (Fig 2 (B), mean of four 

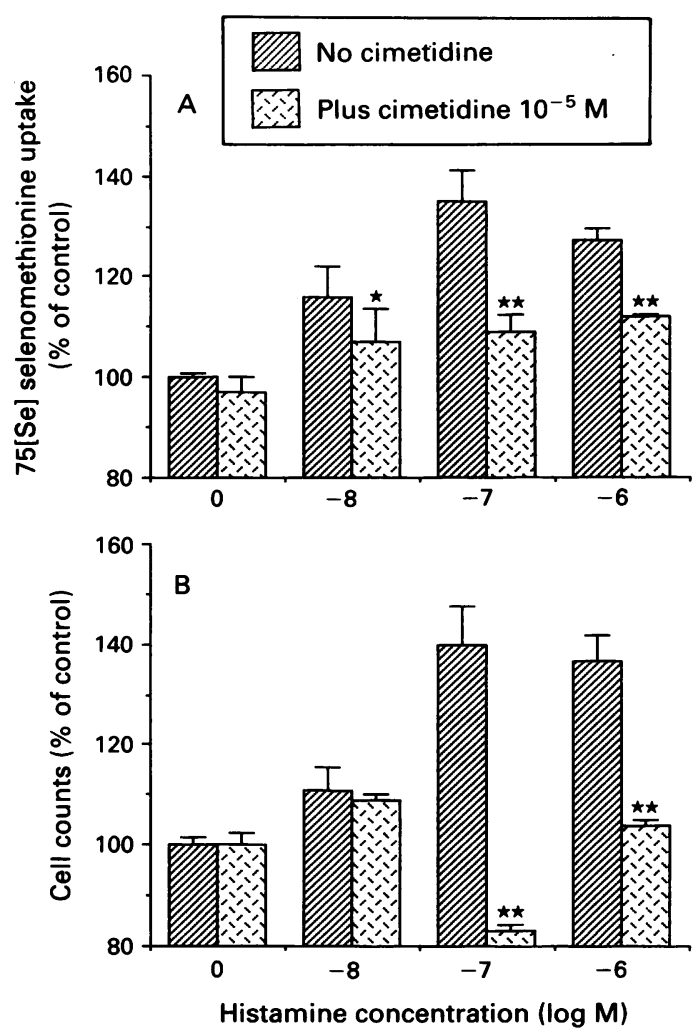

Figure 2: Effect of cimetidine on the histamine stimulated growth of MKN45G as assessed by $(A)^{75}[S e]$

selenomethionine uptake (mean of four experiments) and $(B)$ direct cell counts (mean of four experiments). ${ }^{\star} p<0.01$, $\star \star p<0.001$ when compared with histamine stimulated growth.

separate experiments). Cimetidine had no significant effect on the basal growth.

\section{IN VIVO STUDIES}

As MKN45G responded to histamine in a dose dependant manner, it was decided to perform in vivo studies with the cells grown as xenografts.

\section{Effect of histamine on the basal growth of MKN45G xenograft in nude mice}

Four groups of five nude mice were grafted with

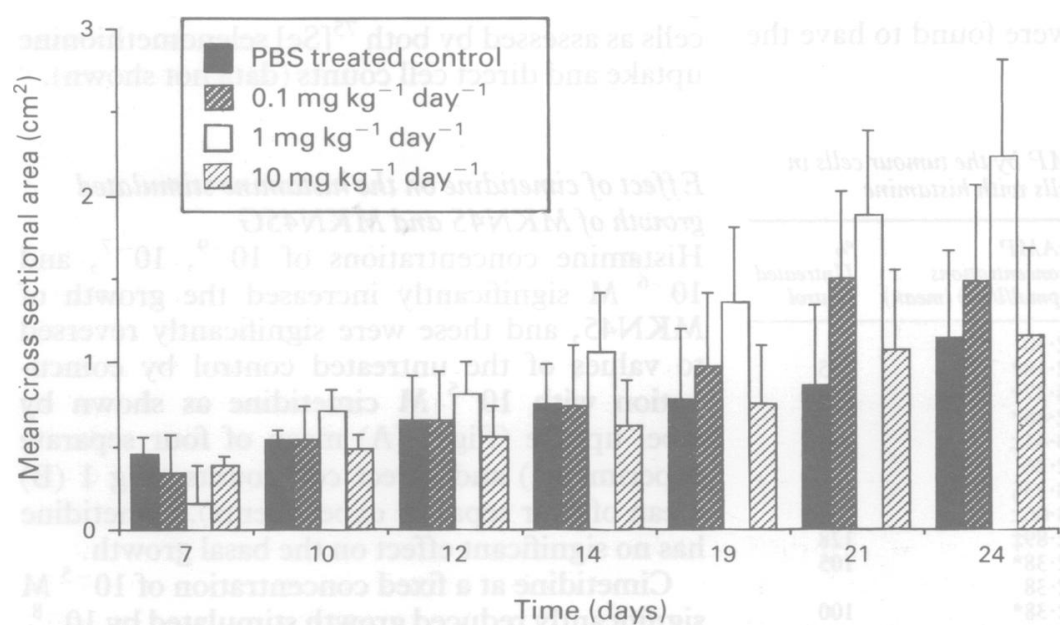

Figure 3: Effect of locally administered histamine on the growth of MKN45G xenografts as assessed by an increase in cross sectional tumour area. $n=5$ micelexperimental group.) $1 \mathrm{mgkg}^{-1}$ day $^{-1}$ histamine treated xenografts were significant from the PBS treated controls at day 21 and day $24(p<0 \cdot 02, p<0 \cdot 05$, respectively Mann-Whitney) and by a MANOVA analysis $(p=0 \cdot 08)$.
MKN45G xenograft tissue and treated with PBS the histamine diluent, $0 \cdot 1,1$, and $10 \mathrm{mgkg}^{-1}$ day ${ }^{-1}$ histamine, locally at the site of the xenograft (Fig 3).

After 21 days growth, xenografts treated with a histamine concentration of $1 \mathrm{mgkg}^{-1}$ had significantly raised mean cross sectional areas ( 2.2 greater than the control, $\mathrm{p}<0.02$, MannWhitney). A two way analysis examining treatment by time was also performed. An analysis of variance for growth was significant $(p<0.001)$ showing that at least one treatment group was significantly different from the control. A MANOVA was performed, which allows serial measurements to be analysed, and xenografts treated with the histamine concentration of $1 \mathrm{mgkg}^{-1}$ were significantly different from the controls $(p=0.008)$ whereas xenografts treated with histamine concentrations of $0 \cdot 1$ and 10 $\mathrm{mgkg}^{-1}$ were not.

Effect of histamine with/without cimetidine on the growth of MKN45G xenografts

Four groups of five nude mice were grafted with MKN45G xenograft tissue and treated with either PBS or histamine at a single concentration of $1 \mathrm{mgkg}^{-1} \mathrm{day}^{-1}$, locally at the tumour site. One group treated with PBS and one group with histamine were also dosed with cimetidine orally in the drinking water at a dose of $100 \mathrm{mg}^{-1} \mathrm{~kg}^{-1}$ day $^{-1}$ (Fig 4).

At day 21, histamine had significantly increased the basal growth of MKN45G to 1.6 more than the control, $\mathrm{p}<0.02$, MannWhitney) and this was significantly reversed by coadministration of cimetidine $(p<0.02$, MannWhitney). Cimetidine inhibited the basal growth of MKN45G to $0.7 \times$ the control $(p<0.05$, Mann-Whitney). These differences were also achieved at day 27, the day the study finished.

Analysis of the data by an analysis of variance for growth showed that the treatment groups were significantly different from the controls $(p<0.001)$ and that there was a treatment with time interaction - that is, the rate of growth was not the same for all treatments $(p<0 \cdot 001)$. Visual analysis of the data showed that the growth rates of the treatment groups were parallel until day 19 and then diverged. Based on these data a MANOVA was performed on the data from day 19 to day 27.

It was found that xenografts treated with histamine were significantly greater than the controls $(p=0.034)$. Cimetidine treated xenografts were also significant from the controls $(p=$ 0.048 ) but cimetidine and histamine treated xenografts were not. Histamine stimulated growth was significant from growth in the presence of cimetidine only $(p<0.001)$ and cimetidine and histamine $(\mathrm{p}<0.001)$.

\section{Histological analysis of histamine and cimetidine} treated $M K N 45 G$ xenografts

Xenografts from the four experimental groups in Figure 4 were analysed blind by an independent pathologist. The histamine treated xenografts were identical to those from the PBS treated control with respect to the number of inflamma- 


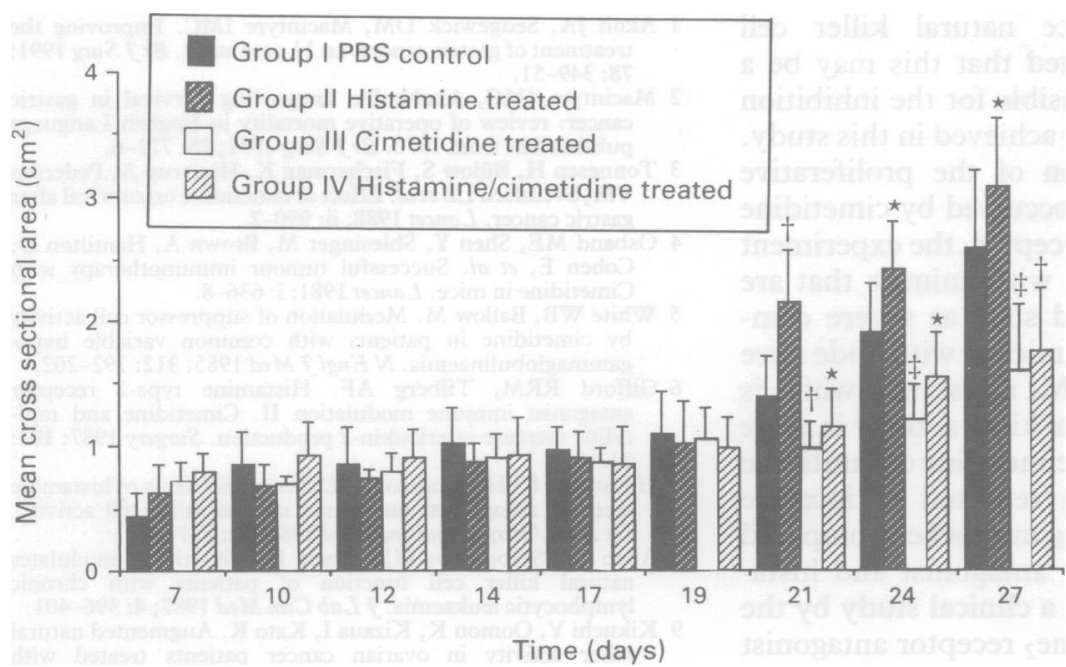

Figure 4: Effect of locally administered histamine $\left(1 \mathrm{mgkg}^{-1} \mathrm{day}^{-1}\right)$ and orally dosed cimetidine (100 mgkg day ${ }^{-1}$ ) on the growth of MKN45G xenografts. Group I PBS control, $n=5$ micelgroup; Group II Histamine treated $n=5$ mice/group; Group III Cimetidine treated, $n=5$ micelgroup; Group IV Histamine/cimetidine treated, $n=4$ mice/group; as assessed by an increase in cross sectional tumour area. ${ }^{\star} p<0.05, t p<0.02, \neq p<0.01$, when compared with the PBS treated controls. Histamine treated xenografts were significantly different from $P B S$ treated control and the cimetidine only and cimetidine plus histamine treated xenografts as assessed by Mann-Whitney and MANOVA $(p=0.034, p<0.001, p<0.001$ respectively for second test). Cimetidine only was also significant from the control as shown by Mann-Whitney and MANOVA $(p=0.048$ for second test $)$.

tory cells, showing that the increase in tumour size was not a result of an inflammatory response to the injected histamine. All xenografts were composed mainly of tumour cells (as deduced from nucleii) and very little tumour stroma. Necrotic areas were present in all tumours in the centre of the xenograft due to the lack of tumour vascularisation.

The cimetidine treated xenografts were identical in all respects to the xenografts from the other groups apart from having less necrotic areas, possibly because they had not outgrown their blood supply to the same extent as the other tumours.

\section{Discussion}

In this study it has been shown by two independent methods that histamine increases the in vitro proliferation of the two gastric tumour cell lines; MKN45 and MKN45G but not the two colorectal lines; $\mathrm{C} 170$ and LoVo. The effects seem to be mediated by the histamine 2 receptor as shown by cAMP accumulation in response to histamine, in the first two cell lines. The optimum histamine concentration for increasing both proliferation and cAMP accumulation is about $10^{-6} \mathrm{M}$ for MKN45G. For MKN45 there seems to be two concentration optima; $10^{-6}$ and $10^{-9} \mathrm{M}$

Histamine has previously been shown to be 10 times less potent in stimulating cAMP concentrations in gastric glands isolated from guinea pig antrum when compared with glands isolated from the fundus $\left(9 \times 10^{-5} \mathrm{M}\right.$ compared with $10^{-5}$ M). ${ }^{15}$ The histamine concentrations effective in stimulating antral gastric glands are close to those inducing optimal effects in the MKN45G cell line, which is gastrin producing. It is not stated by the originator as to the exact site of the primary tumour from which MKN45 and
MKN45G were derived ${ }^{10}$ but because of the gastrin secretory nature of MKN45G it could possibly have been in the antrum. MKN45 cells responded optimally to two different histamine concentrations. The reason for this is not known but the proliferative effects seen at both histamine concentrations were effectively reversed by the histamine 2 receptor antagonist, cimetidine, indicating the presence of histamine ${ }_{2}$ receptors with differing affinities on MKN45 cells. Evidence for the presence of histamine 2 receptors on MKN45 has also been shown by Arima et al. ${ }^{16}$

It is interesting to note that the human gastric tumour cell line HGT-1, which was derived from a primary tumour originating in a non-antral part of the stomach, ${ }^{17}$ had a histamine ${ }_{2}$ receptor which responded, maximally to much higher histamine concentrations of $10^{-3}$ to $10^{-4} \mathrm{M}$. Cells from the duodenum did not possess the histamine $_{2}$ receptor $^{15}$ and in this study it was shown that two colorectal tumour cell lines did not seem to possess histamine ${ }_{2}$ receptor indicating location of histamine ${ }_{2}$ receptor may be confined to the gastric area.

Cimetidine had no direct anti-tumour effects on the basal growth of the two gastric and two colorectal tumour cell lines examined in this study, which is in accord with the findings of Scotcher et al. ${ }^{18}$ Cimetine reversed the histamine stimulated proliferation of the first two cell lines, however, at a concentration of $10^{-5} \mathrm{M}$, which corresponded to the cimetidine concentration that induced complete inhibition of histamine on cAMP accumulation in guinea pig fundus and antrum $^{15}$

When given locally, in vitro, histamine increased the proliferation of grafted MKN45G tumour tissue in nude mice. Histological analysis showed that the size increase was not due to a local inflammatory response. Also both control and histamine treated tumours had a similar proportion of malignant cells, stroma, and vascularisation, suggesting direct proliferative effects on the xenograft may have been responsible for the increased size. Cimetidine was shown to reverse this histamine stimulated growth, in vivo. Unlike the in vitro findings, however, cimetidine reduced the basal growth of MKN45G xenografts.

Previous studies examining the in vivo effects of cimetidine have been performed on syngeneic tumour models with immunocompetent animals. Cimetidine slowed the metastatic development and increased the survival in mice with the Lewis lung carcinoma, 3LL despite the tumour having no histamine ${ }_{2}$ receptor. ${ }^{3}$ While having no direct anti-tumour effect on the cells in vitro, it was found that cimetidine inhibited suppressor $T$ cells allowing the initial antitumour response affecting cytotoxic $T$ cells to persist and be effective. In a second study by Gifford $e t a l,{ }^{14}$ cimetidine had a protective effect in mice implanted with two different syngeneic tumours; lymphoid ascitic cells and a fibrosarcoma despite the cells being unaffected by the agent in vitro. Again, inhibition of suppressor cell activity was postulated to be responsible.

In this study, nude mice were used that do not possess mature $T$ lymphocytes but do have natural killer cell activity. ${ }^{19}$ As cimetidine has 
been shown to enhance natural killer cell cytoxicity $^{7-9}$ it is postulated that this may be a mechanism partly responsible for the inhibition of basal xenograft growth achieved in this study. To find out if inhibition of the proliferative effects of histamine also occurred by cimetidine blockade of histamine 2 receptor, the experiment will need to be repeated with animals that are further immune depleted such as severe combined immune deficiency mice or with nude mice treated with anti-asialo GM1 antiserum, which is known to eliminate natural killer activity in nude mice.$^{20} \mathrm{~A}$ combination of cimetidine or ranitidine and histamine has been reported to increase survival in tumour bearing mice when compared with histamine ${ }_{2}$ receptor antagonist and histamine only controls. ${ }^{2122}$ In a clinical study by the same authors, ${ }^{23}$ a histamine ${ }_{2}$ receptor antagonist histamine combination resulted in enhanced survival over untreated controls. The authors postulated that while histamine ${ }_{2}$ receptor blockade decreased $T$ cell suppression, stimulation of histamine ${ }_{1}$ receptor by histamine increased vascular permeability and enhanced intratumoral penetration of humoral and cellular elements of the immune response.

In this study, when only histamine was given to nude mice, increased vascular permeability mediated by interaction with histamine ${ }_{1}$ receptor may have led to an enhancement of xenograft growth due to increased diffusion of nutrents etc, in addition to direct proliferative effects by a histamine ${ }_{2}$ receptor. When cimetidine was given together with histamine, blockade of histamine 2 receptor may have reversed histamine stimulated growth. If natural killer cell activity is increased, the growth promoting effects of enhanced vascular permeability may be counterbalanced by greater access of the natural killer cells to the tumour. This may be why in our study, histamine and cimetidine together had similar inhibitory effects in vivo as cimetidine alone.

Tumours arising within the stomach may be in direct contact with local agents, capable of increasing their proliferation. This should be taken into account in the development of potential anti-tumour and anti-ulcer treatments.

The authors would like to thank SmithKline Beecham for funding the study. Also the authors thank Miss D Milanowska for typing the script, Dr R Hewitt for performing the histological studies, the script, Dr R Hewitt for performing the histological
and Dr L Rushton for performing the statistical analyses.

and Dr $L$ Rushton for performing the statistical analyses.
Part of the manuscript has previously been published in abstract form Gut 1991; 32: A589.
1 Akoh JA, Sedgewick DM, Macintyre IMC. Improving the treatment of gastric cancer: an 11 year audit. Brf Surg 1991 78: 349-51.

2 Macintyre IMC, Akoha JA. Improving survival in gastric cancer: review of operative mortality in English Languag publications from 1970. Brf Surg 1991; 78: 771-6.

3 Tonnesen H, Bülow S, Fischerman K, Hiortrup A, Pedersen $V M$, Svendsen $L B$ et al. Effect of cimetidine on survival after gastric cancer. Lancet 1988; ii: 990-2.

4 Osband ME, Shen Y, Shlesinger M, Brown A, Hamilton D, Cohen E, et al. Successful tumour immunotherapy with Cimetidine in mice. Lancet 1981; i: 636-8.

5 White WB, Ballow M. Modulation of suppressor cell activity by cimetidine in patients with common variable hypogammaglobulinaemia. $N$ Englf Med 1985; 312: 192-202.

6 Gifford RRM, Tilberg AF. Histamine type-2 receptor antagonist immune modulation II. Cimetidine and ranitidine increase interleukin-2 production. Surgery 1987; 102 242-7,

7 Hellstrand K, Hermodsson S. Differential effects of histamine receptor antagonists on human natural killer cell activity. Int Arch Allergy Appl Immunol 1987; 84: 247-55.

8 Allen JI, Syropoulos HJ, Grant B. Cimetidine modulates natural killer cell function of patients with chronic lymphocytic leukaemia. F Lab Clin Med 1987; 4: 396-401.

9 Kikuchi V, Oomon K, Kizaua I, Kato K. Augmented natura killer activity in ovarian cancer patients treated with killer activity in ovarian cancer patients treated
cimetidine. Eur $\mathcal{F}$ Cancer Clin Oncol 1986; 22: 1037-43.

10 Hojo J. Establishment of cultured cell lines of human stomach cancer origin and their morphological characteristics. Niigata Igakukai Zasshi 1977; 91: 737.

11 Watson SA, Durrant LG, Wencyk PM, Watson AL, Morris DL. Intracellular gastrin in human gastrointestina tumoured cells. $\mathcal{F}$ Natl Cancer Inst 1991; 83: 866-71.

12 Drewinko B, Ronsdahl MM, Yang LY, Ahearn MJ, Trujillo JM. Establishment of a human carcinoembryonic antigenproducing colon adenocarcinoma cell line. Cancer Res 1976; 36: 467-75.

13 Durrant LG, Robins RA, Pimm MV, Perkins AC, Armitage NC, Hardcastle JD, et al. Antigenicity of newly established
colo-rectal carcinoma cell lines. Br $\mathcal{C}$ Cancer $1986 ; 53: 37-45$.

14 Gifford RRM, Ferguson RM, Voss BV. Cimetidine reduction of tumour formation in mice. Lancet 1981; ii: 638-40.

15 Gespach C, Hui Bon Hoa D, Rosselin G. Regulation by Vasoactive intestinal peptide, Histamine, Somatostatin-14 and 28 of cyclic adenosine monophosphate levels in gastric glands isolated from the guinea pig fundus or antrum. Endocrinology 1983; 112: 1597-606.

16 Arima N, Yamashita Y, Morishita T, Fujita T, Nakamura A, Nakata $\mathrm{H}$, et al. Presence of histamine $\mathrm{H} 2$ receptor on poorly
differentiated human gastric cancer cell line, MKN45. Nippon Shokakibyo Gakkai Zasshi 1991; 81: 115.

17 Laboisse CL, Augeron C, Couturier-Turpin M, Gespach C, Cheret A, Potet F. Characterisation of a newly established human gastric cancer cell line HGT-1 bearing histamine $\mathrm{H}_{2}$ human gastric cancer cell line HGT-1 beari

18 Scotcher S, Sikora K. Gastric cancer and cimetidine: dose delay in diagnosis matter. Lancet 1981; ii: 630-1.

19 Herberman RB. Natural cell-mediated cytotoxicity in nude mice. In: Fogh J, Giovanella BC, eds. The nude mouse in experimental and clinical research. New York: Academic Press, 1978: 135-45.

20 Habu S, Fukui H, Shimamura K, Kasai M, Nagai Y, Okumura $\mathrm{K}$, et al. In vivo effects of anti-asialo $\mathrm{GM}$. Reduction of NK activity and enhancement of transplanted tumour growth in nude mice. F Immunol 1981; 127; 34-8.

21 Burtin C, Scheinmann P, Fray A, Lespinats G, Noirot C, Paupe J. Ranitidine and cancer. N Engl f Med 1984; 310: 1603.

22 Burtin C, Scheinmann P, Salomon JC, Lespinats G, Canu P Decrease in tumour growth by injections of histamine or serotonin in fibrosarcoma-bearing mice: influence of $\mathrm{Hl}$ and H2 histamine receptors. Brf Cancer 1982; 45: 54-60

23 Burtin C, Noirot C, Scheinmann P, Galoppin L, Sabolovic D, Bernard $P$. Improvement in advanced cancer disease after treatment combining histamine and $\mathrm{H} 2$-antihistaminics (ranitidine or cimetidine). Eur $\mathcal{F}$ Cancer Clin Oncol 1988; 24: 161-7. 